\title{
Türkiye’deki Öğrencilerin Fen Bilimleri PISA Testleri Sonuçlarının Fizik Öğretmen Adayları \\ Tarafından Değerlendirilmesi
}

\section{Medine BARAN*, Mukadder BARAN"*, Abdulkadir MASKAN****}

Öz: Bu araştırmada fizik öğretmenliği anabilim dalında eğitim görmekte olan öğretmen adaylarının PISA'dan haberdar olup olmadıkları ve Türkiye'deki öğrencilerin PISA fen bilimleri testi sonuçlarına yönelik görüşlerinin değerlendirilmesi amaçlanmıştır. Araştırma toplamda 49 fizik öğretmen adayı ile yürütülmüştür. Araştırmada veri toplama aracı olarak 8 soruluk yapılandırılmış görüşme formu kullanılmıştır. Araştırmadan elde edilen veriler içerik analizi ve betimsel analiz yöntemleri ile analiz edilmiştir. Katılımcı gruptaki 49 öğrenciden sadece sekiz öğrencinin program hakkında doğru bilgi sahibi olduğu görülürken bir öğrencinin ise yanlış bilgi sahibi olduğu saptanmıştır. Araştırmaya katılan grubun Türkiye fen PISA testleri sonuçlarına yönelik görüşleri incelendiğinde, fizik öğretmen adaylarının olumsuz PISA test sonuçlarını eğitim sistemi, okul, ders programı, öğretmen ve mevcut sınav sistemindeki sorunlara bağlı bir şekilde açıkladıkları görülmüştür. Bununla beraber katılımcı gruptaki fizik öğretmen adayları fen okuryazarlığının artırılmasına yönelik olarak, fen alanları öğretmenlerinin yöntem-tekniklerini değiştirerek öğrenci merkezli yaklaşımları benimsemesi ve eğitim sisteminin değiştirilmesi gerektiği gibi çeşitli önerilerde bulunmuşlardır.

Anahtar kelimeler: PISA, Fizik öğretmen adayları, görüş.

*Doç.Dr. Dicle Üniversitesi, Eğitim Fakültesi, Diyarbakır, Orcid.org/0000-0001-5813-6494 medabaran@ gmail.com

**Öğrt. Üy. Dr. Hakkari Üniversitesi, Eğitim Fakültesi, Orcid.org/ felekbaran@ hotmail.com

***Prof. Dr. Dicle Üniversitesi, Eğitim Fakültesi, Diyarbakır, Orcid.org/0000-0002-0566-6376 akmaskan@ gmail.com

Gönderim:31.08.2018 Kabul:11.10.2018 Yayın:15.12.2018




\title{
Evaluation of Physics Teacher Candidates' Opinions towards Turkish Students' PISA Science
}

\section{Tests Results}

\begin{abstract}
In this study it was aimed to evaluate whether preservice teachers are aware of the PISA and their views about exam of the PISA science results of the students in Turkey. The research was conducted with a total of 49 physics teacher candidates. A fully structured interview form with 8 questions was used as data collection tool in the research. The data obtained from the research were analyzed with content analysis and descriptive analysis methods. Of the 49 students in the participating group, only eight students were found to have the correct information about the program, while a student was found to have the wrong information. When the opinions of the participating group were analyzed for Turkey PISA test results, it has been seen that the physics teacher candidates explain the negative PISA test results depending on the problems in the education system, school, course curriculum, teacher and current examination system. However, the physics teacher candidates made various suggestions to increase science literacy, such as adopting student-centered approaches by changing science teachers' method-techniques and changing the education system.
\end{abstract}

Key words: PISA, Science, Physics teacher candidates, views.

\section{Giriş}

21. Yüzyıl bireyinden beklenen, bilgi deposu olmak değil, bilginin uygulanmasını ve sentezini yapabilecek düzeyde olabilmektir. Bunun yolu ise nitelikli eğitimden geçmektedir. Eğitimin başlıca işlevi, öğrenen bireyin bilgiyi, eleştirel, sorgulayııı bir şekilde alması ve kendi zihinsel süzgecinden geçirerek yapılandırması olarak tanımlanabilmektedir. Böylelikle anlamlı öğrenme de gerçekleşecektir. Bu durum, okul öncesi eğitimden başlayarak yüksek öğretim ve daha sonraki aşamalar olmak üzere zincirleme bir etki yapması ve dolaylı olarak toplumun genel yapısını 
etkilemesi açısından çok önemli bir role sahiptir. Bu noktada eğitim sistemlerinin ne kadar nitelikli işlediği noktası önem kazanmaktadır. Bunun için gerek ulusal gerekse uluslararası düzeyde çeşitli ölçme ve değerlendirme mekanizmaları vardır. Bunlardan biri lise öğrencileri on beş yaş grubuna uygulanan uluslararası öğrenci değerlendirme programı olan PISA'dır (Uluslararası Öğrenci Değerlendirme Programı). Bu program ile öğrencilerin matematik, fen ve okuma alanlarında eğitim yolu ile kazandıkları temel becerileri ölçmek ve değerlendirmek amacı ile tarama çalışması yapılır. PISA çerçevesinde yapılan sınavlar, OECD (İktisadi İşbirliği ve Kalkınma Teşkilatı) ülkelerinde yaşayan lise öğrencisi 15 yaş grubu öğrencilerinin aldıkları eğitimin sonunda, yaşadıkları bilgi toplumunda karşılaşabilecekleri durumlara karşı ne düzeyde hazırlıklı olduklarını belirlemek amacıyla yapılmaktadır (Çelen, Çelik ve Seferoğlu, 2011). Bu programa Türkiye'deki öğrenciler de 2003 yılından itibaren dahil olmaktadırlar. “PISA 2003 ve 2006'ya katılan Türkiye 'nin hangi düzeyde bulunduğunun belirlenmesi ve bazı değişkenler açısından değerlendirilmesi, özellikle Türk Ĕ̆itim Sistemi'ne yeni bir vizyon oluşturma aşamasında önem kazanmaktadır” (Sarıer, 2010, s.113). Bu bağlamda PISA çerçevesinde uygulanan testlerin sonuçlarına bakıldığı zaman, Türkiye'deki katılımcı öğrencilerin başarı ortalamalarının bir çok ülkeye oranla oldukça düşük olduğu görülmüştür. Bu sonuç beraberinde eğitim siteminin sorgulanmasını da getirmiştir. Eğitimin çeşitli alanlarında çalışmalar yapan kişiler bu durumun nedenlerine yönelik araştırmalar yapmışlardır. Fakat tüm bunlarla beraber PISA testlerinde Türkiye'den katılan öğrenciler, matematik, fen ve okuma becerileri alanlarında halen istenilen başarıyı gösterememişlerdir. Bu noktadan hareketle Türkiye'deki öğrencilerin bilgiye eleştirel ve sorgulayıcı yaklaşmaları, kazanılan bilgiyi uygulama noktalarında problemler yaşadıklarını söylemek mümkündür. Bununla direk bağlantılı olarak eğitim sisteminde sorun ve sıkıntıların devam ettiğini de söylemek mümkündür.

2003 yılından itibaren yapılan PISA sınavları sonuçlarının hepsinde de Türkiye'deki öğrenciler her üç konu alanında da OECD ülkelerini içeren genel sıralamada son sıralarda ve genel ortalamanın altında yer almışlardır. Bu noktada sıralamada en iyi olanlara bakılırken Finlandiya'daki öğrencilerin 
en başarılı grup olduğu görülmüştür. Finlandiya'daki öğrencilerin PISA sınavlarında gösterdiği başarı dikkat çekmiştir. Bu başarının sırları bir çok bilim insanı ve eğitimci tarafından incelenip anlaşılmaya çalışılmaktadır (Eraslan, 2009). Bu durumdan yola çıkarak uluslararası sınavlarda başarılı olmak için eğitim sisteminde neler yapılması gerektiği sorgulanmaya başlanmıştır.

Eğitim sistemi sorgulanırken, eğitim sistemin en önemli bileşenlerinden olan öğretmenlerin de ele alınması gerekmektedir. Öğrencilerin bilgiye ulaşmasında ve anlamlı öğrenmenin gerçekleşmesinde öğretmenler çok büyük rollere sahiptir. Eğitim sisteminin niteliğini etkileyen en önemli faktörler arasında olan öğretmen, hem alan bilgisi hem de pedagojik formasyon açısından donanımlı olmak durumundadır. $\mathrm{Bu}$ noktadan hareketle eğitim sistemindeki başarının, eğitim kurumlarına hizmet vermek üzere öğretmen yetiştiren eğitim fakültelerinin eğitim kalitesi ile direk olarak bağlantı halinde olduğu söylenebilir. Eğitim fakültesinden mezun olan öğretmenlerin çağın şartlarına uygun bir donanıma sahip olması gerekmektedir. Öğretmenin uluslararası eğitim programlarından haberdar olması, bu programlar ile Türkiye' deki programları karşılaştırma yapabilme, eksik ve üstün yanlarını analiz etme becerilerine sahip olması daha nitelikli bir eğitim sisteminin önünü açacaktır. Bu yüzden eğitim fakültelerindeki öğretmen adaylarının eğitim alanlarındaki gelişmelerden haberdar, bilinçli ve donanımlı olarak yetiştirilmesi, okuduğunu anlayan, yorumlayan ve uygulayan bir neslin yetişmesi açısından oldukça önemli görülmektedir.

\section{Araştırmanın Önemi}

Yapılan literatür taramasında öğretmen veya öğretmen adaylarının uluslararası eğitim programlarına, değerlendirme sistemlerine yönelik görüşlerini inceleyen bir çalışmaya rastlanmamıştır. Literatürdeki bu boşluk göz önüne alınarak yapılan bu araştırmada fizik öğretmenliği anabilim dalında eğitim görmekte olan öğretmen adaylarının PISA sınavlarından haberdar olup olmadıkları ve Türkiye'deki öğrencilerin PISA fen bilimleri sınavı sonuçlarına yönelik görüşlerinin 

düşünülmektedir.

\section{Yöntem}

$\mathrm{Bu}$ araştırma, nitel araştırma yöntemi kullanılarak yapılmıştır. Olgu bilim deseninin kullanıldı̆̆ bu çalışmada elde edilen verilere görüşme formu kullanılarak ulaşılmıştır.

\section{Katılımcılar}

Araştırma toplamda 49 fizik öğretmen adayı ile yürütülmüştür. Araştırmanın katılımcılarını Marmara bölgesinde bulunan bir devlet üniversitesinin fizik öğretmenliği bölümünde eğitim görmekte olan 3 . $(n=12), 4$. $(n=16)$ ve 5. $(n=12)$ sınıf öğrencileri oluşturmaktadır. Araştırmaya katılan katılımcılardan 9 tanesi ise sınıfını belirtmemiştir. Bununla beraber araştırmaya katılan fizik öğretmen adaylarının 29'u kadın, 17'si erkek iken 3'ü ise cinsiyetini belirtmemiştir. Araştırmanın çalışma grubunu oluşturan katılımcılar ulaş1labilirlik durumuna göre belirlenmiştir.

\section{Veri Toplama Araçları}

Araştırmada veri toplama aracı olarak 8 soruluk tam yapılandırılmış görüşme formu kullanılmıştır. Araştırmada kullanılan veri toplama aracının öncelikle pilot çalışması yapılmıştır. Araştırmacılar tarafından hazırlanan PISA uygulamalarına yönelik fizik öğretmen adaylarının görüşlerini elde etmek amacı ile hazırlanan taslak sorular, araştırmanın yapıldığı üniversiteden farklı olarak eğitim fakültesi fizik öğretmenliği anabilim dalı çeşitli sınıflarında eğitim görmekte olan öğrencilere yöneltilmiştir. Araştırmacılar ve bir başka konu uzmanı öğretim üyesi tarafından incelenen pilot çalışma verilerinden yola çıkılarak araştırmanın amacına hizmet edecek, açık ve net olan sorular belirlenmiştir. Araştırmada kullanılan veri toplama aracının güvenirlik ve geçerliğini sağlamak amacıyla iki ayrı konu uzmanı (ölçme ve değerlendirme) araştırmacı tarafından değerlendirilmiştir. Yapılan değerlendirme sonucunda üzerinde görüş birliğine varılan sorular görüşme formunda bırakılmış, 
diğerler sorular ise elenmiştir. Bu değerlendirme sonucunda veri toplama aracındaki soru sayısı sekiz olarak belirlenmiştir.

\section{Uygulama Süreci}

Uygulama yapılmadan önce fizik öğretmen adaylarına PISA'dan haberdar olup olmadıkları sorulmuştur. Daha sonra katılımcı fizik öğretmeni adaylarına PISA testlerinin içeriğini açıklayan ve Türkiye'den katılan öğrencilerin 2006 yılından itibaren Fen bilimleri ve diğer alanlardaki başarı ortalamalarını gösteren aşağıdaki tablonun olduğu yazılı bir döküman verilmiştir.

Tablo 1

Türkiye’nin PISA 2006, 2009 ve 2012 Yıllarına Ait Fen, Matematik ve Okuma Başarı Puanları

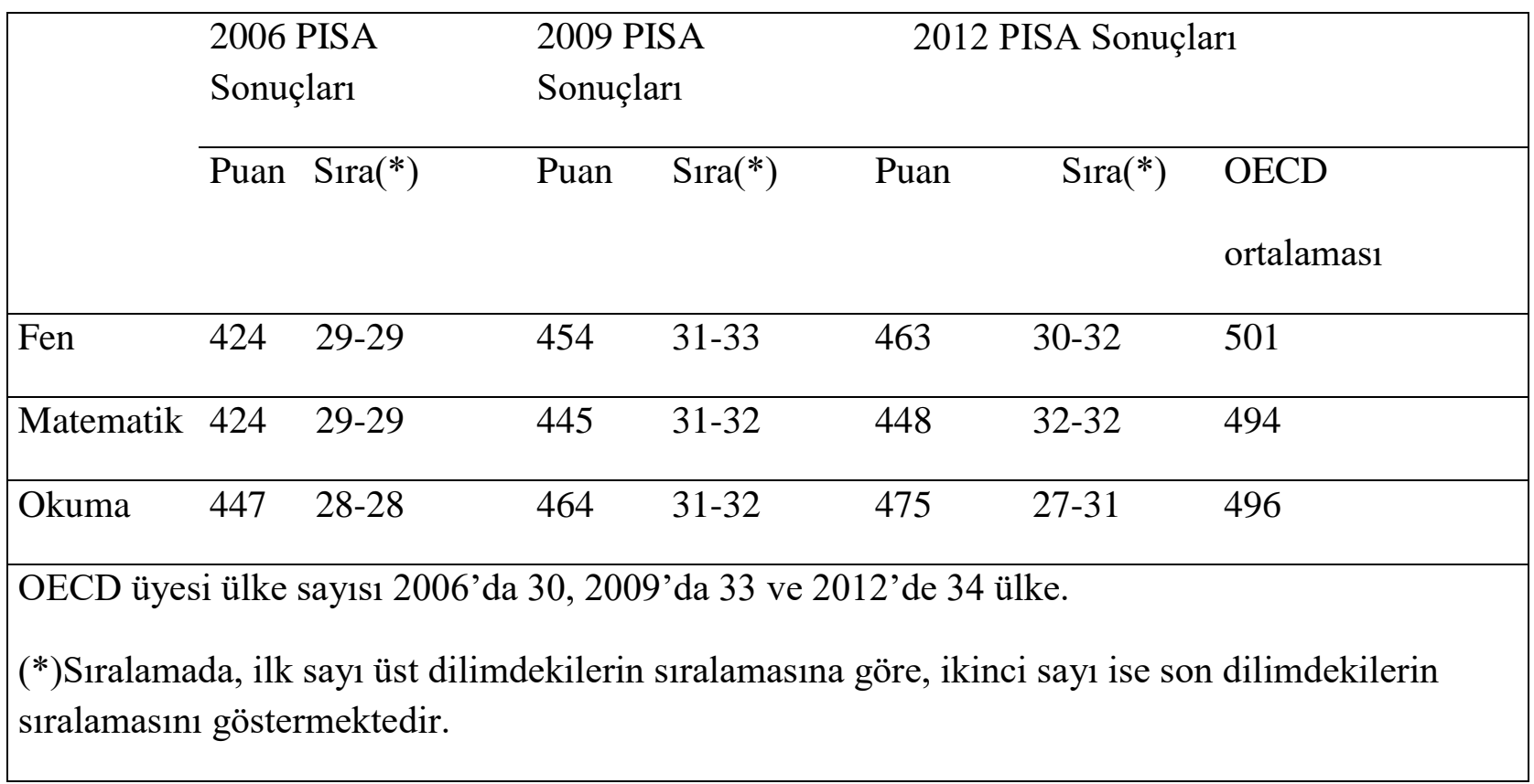

Böylelikle katılımcı öğretmen adaylarının, hem PISA'nın içeriği hem de Türkiye'deki öğrencilerin fen bilimleri alanlarındaki başarıları hakkında bilgi sahibi olmaları sağlanmıştır. Bu aşamadan sonra araştırmaya katılan fizik öğretmen adaylarına sekiz sorudan oluşan açık uçlu soru formları 
dağıtılmıştır. Uygulamalar her sınıf için ayrı olmak üzere yaklaşık olarak bir ders saati kadar (50 dakika) sürmüştür.

\section{Verilerin Analizi}

Araştırmadan elde edilen veriler içerik analizi ve betimsel analiz yöntemleri ile analiz edilmiştir. Araştırmadan elde edilen verilerin içerik analizi araştırmacılar tarafından yapılmıştır. Yapılan karşılaştırmaların sonunda araştırmanın güvenirliği test edilmiştir. Araştırmanın güvenirliği test edilirken Miles ve Huberman'ın (1994) güvenirlik hesaplama yönteminden faydalanılmıştır. Bu aşamada iki araştırmacı tarafından yapılan nitel analiz sonuçları karşılaştırılmış, üzerinde görüş birliği olan konular ve görüş birliği olmayan konular temel alınarak bir hesaplama yapılmıştır. Böylelikle kodlayıcılar arasındaki uyuma bakılmıştır. Örneğin bir kodlayıcının analizinde PISA ve Türkiyede'ki sınav karşılaştırmasına yönelik kodlar PISA'dan haberdarlık temasında yer alırken diğer araştırmacı benzeri kodları PISA ve mevcut sınavlar arasındaki ilişki teması altında toplamıştır. Araştırmacılar arasında yapılan değerlendirmeden sonra söz konusu ortak kodlar birleştirilerek PISA ve mevcut sınavlar arasındaki ilişki teması altında ifade edilmiştir. Bu şekilde araştırmacılar tarafından yapılan analizlerde görüş birliği içinde olunan ve olunmayan konular belirlenmiştir. Üzerinde görüş birliğine varılan konular, görüş birliği içinde olunan ve olunmayanların toplamına bölünmüş ve yüzdeliğine bakılmıştır. Yapılan hesaplamanın sonunda araştırmanın güvenirliği \% $\% 6$ olarak bulunmuştur.

\section{Bulgular}

Veri toplama aracinın uygulanması ile toplanan verilerin analizi sonucunda elde edilen bulgular, bu bölümde araştırmanın amaçlarına ve önemine dayalı olarak tablolaştırılmış ve açıklanmıştır.

Tablo 2

Katılımcı öğretmen adaylarının PISA sınavlarından haberdarlık durumlarına ilişkin analiz sonuçları 
$\mathrm{Kod}$

\section{Açıklama}

Sy $\mathrm{f}$

Fikri yok

PISA'nın ne

olduğu 3

$\begin{array}{lll}10 & 13 & 8\end{array}$

4 f 5

f 5

$\mathrm{Cy} \quad \mathrm{fk} \quad \mathrm{Fe} \quad \mathrm{Ft}$

hakkında herhangi bir bilgisi

yok

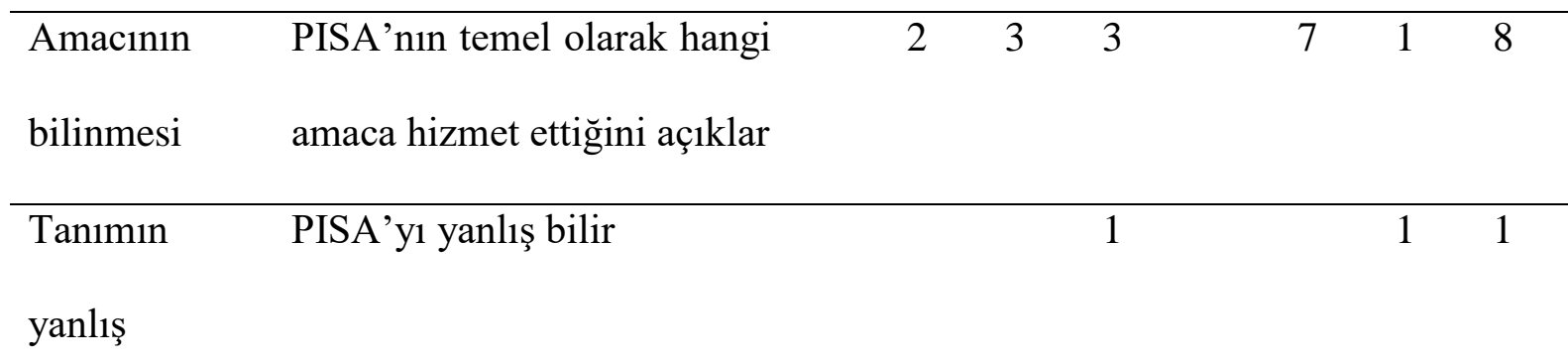

bilinmesi

f3: 3. Sinıfta okuyanların frekansı f4: 4. Sinıfta okuyanların frekansı f5: 5. Sinıfta okuyanların frekansı Sy: Sınıfını yazmayanların frekansı Cy: cinsiyetini yazmayanların frekansı fk: kadınların frekansı fe: erkeklerin frekansı ft: toplam frekans

Araştırmanın sonunda elde edilen veriler analiz edildiğinde, araştırmaya katılan fizik öğretmen adaylarına PISA programı sınavlarından haberdar olup olmadıklarına yönelik sorulan soruya, 49 öğrenciden 40’1 PISA sınavları hakkında hiçbir bilgisinin olmadığı yönünde cevap vermişlerdir. Katılımcı gruptaki sekiz öğrencinin program hakkında doğru bilgi sahibi olduğu görülürken bir öğrencinin ise yanlış bilgi sahibi olduğu saptanmıştır.

\section{Tablo 3}

Katılımcı öğretmen adaylarının PISA sınavlarındaki fen okuryazarlık başarısızlığına etki eden durumlar teması eğitim sistemi ve okul kaynaklı kategorisine yönelik görüşleri

\begin{tabular}{|lllllllllll}
\hline Kod & Açıklama & Sy & f 3 & f 4 & f 5 & Cy & fk & fe & Ft
\end{tabular}




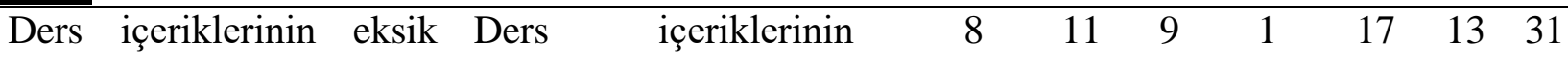

oluşu ve sınava yönelik ezbere, sinavlara 1

oluşu ezbere oluşu yönelik oluşu,

öğrenciyi motive edici

olmamas1.

Fen okur yazarlığa önem Eğitim sisteminin fen 1

$1 \quad 1 \quad 2$

verilmemesi

okur yazarlığa önem

vermemesi.

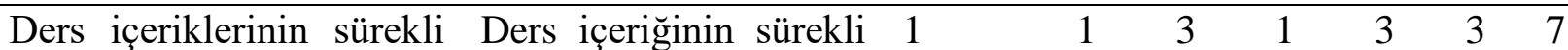

değişiklik arz etmesi kısa süreli aralıklarla

değişmesi başarısızlığa

neden olmakta.

\begin{tabular}{lllllllll}
\hline Eğitim & öğretim & Okul ortamında yeterli & 1 & 2 & 1 & 2 & 2 & 4
\end{tabular}

materyalinin eksik olması araç ve materyalin

olmamas1.

\begin{tabular}{lllllll}
\hline Öğrencinin & öğrenme & Öğrencinin & fen & 1 & 1 & 1
\end{tabular}

ortamlarında fen derslerine derslerine ilgisinin

ilgisiz oluşu azlığ

\begin{tabular}{lllllll}
\hline Eğitime & yatırım & Eğitim & sistemine & 2 & 1 & 3
\end{tabular}

yapılmamas1 gerekli yatırımın

yapılmamas1.

\begin{tabular}{llllllllllll}
\hline Uygulamalı & eğitimin & Eğitimin & daha & çok & 1 & 2 & 1 & & 3 & 1 & 4
\end{tabular}

eksikliği teorik yapılması.

Tablo 3 incelendiğinde, katılımcı öğrenciler eğitim sisteminin sınava yönelik ve ezbere yöneltici olduğuna, öğrencilerde fen derslerine yönelik ilgi uyandırmadığı, ders içeriklerinin sık sık değiştiği, 
uygulamalı eğitimin yapılmadığı, eğitime yapılan yatırımın yeterli olmadığg gibi noktalara vurgu yapmışlardır.

Tablo 4

Katılımcı öğretmen adaylarının PISA sınavlarındaki fen okuryazarlık başarısızlığına etki eden durumlar teması Öğretmen etkisi kategorisine yönelik görüşleri

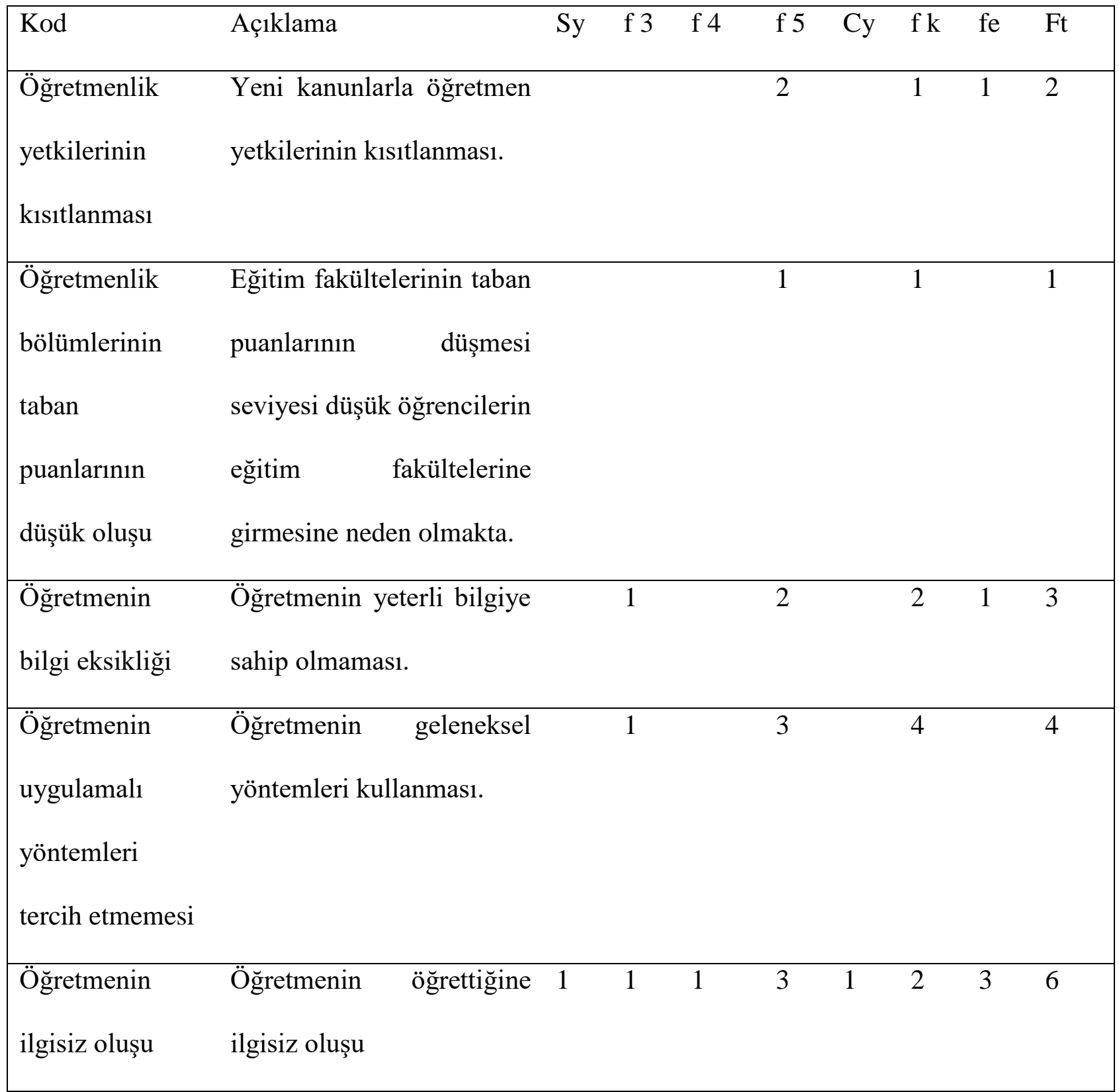

Tablo 4'teki bulgulara bakıldığında katılımcı öğretmen adayları öğretmenlerin ilgisiz olduğunu, uygulamalı yöntem ve teknikleri kullanmadıklarını, donanımlarının yeterli olmadığını, öğretmenlik 
taban puanlarının düşük olduğunu ifade etmişlerdir. Bu durumların da öğrencilerin PISA fen testleri başarısını olumsuz yönde etkilediğini belirtmişlerdir.

Tablo 5

Katılımcı öğretmen adaylarının PISA sınavlarındaki fen okuryazarlık başarısızlığına etki eden durumlar teması toplum etkisi kategorisine yönelik görüşleri

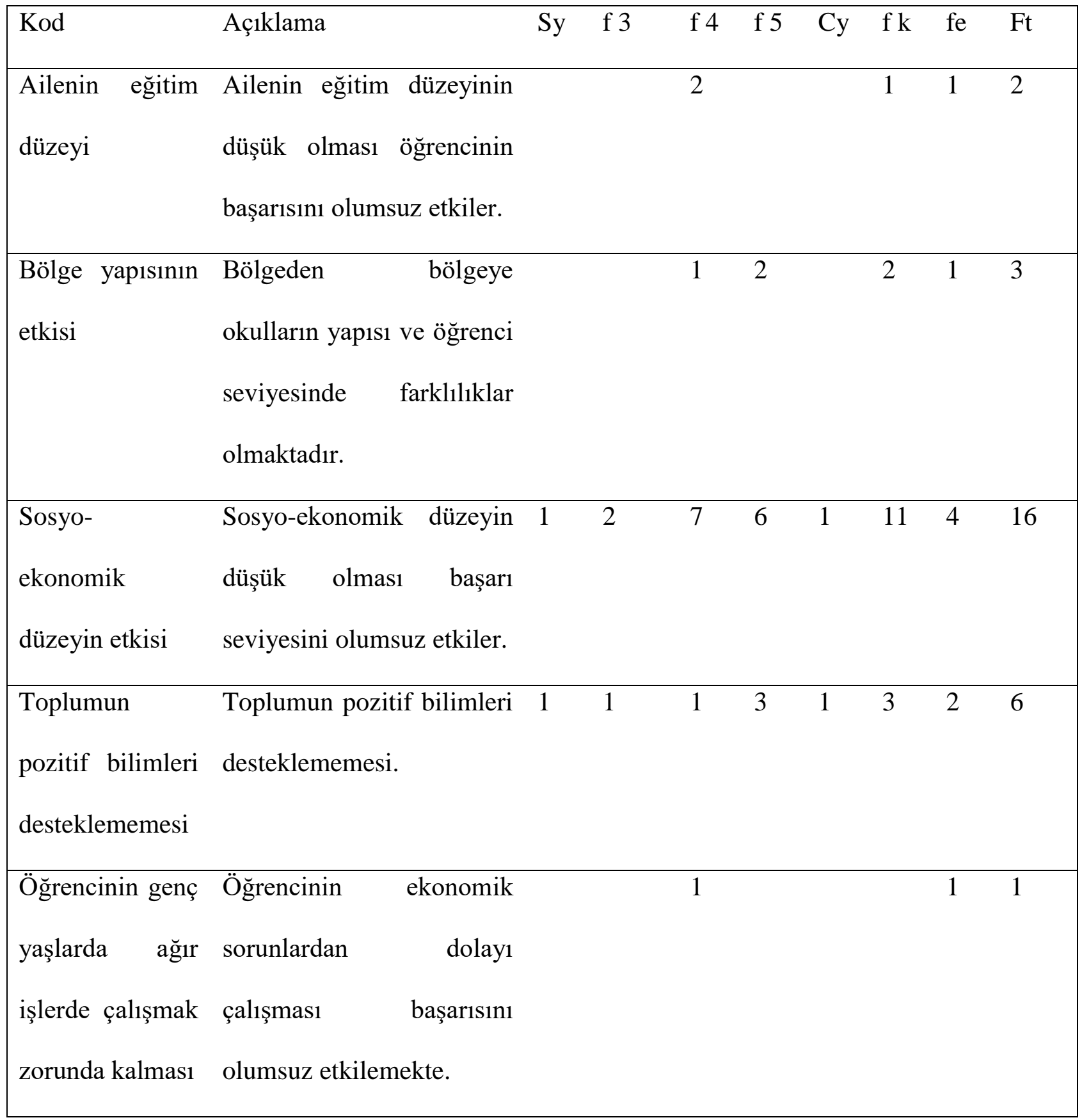


Tablo 5'teki ifadelere bakıldığında katılımcıların, bazı toplumsal özelliklerin PISA fen okuryazarlık başarısını olumsuz etkilediğini belirttikleri görülmüştür. Katılımcılar, ailenin eğitim düzeyinin, toplumun sosyoekonomik yapısının, fen bilimlerine toplumun olumsuz yaklaşımının öğrencilerin başarısı üzerinde olumsuz etkilerde bulunduğunu ifade etmişlerdir.

Tablo 6

Katılımcı öğretmen adaylarının PISA sınavlarındaki fen okuryazarlık başarısızlığına etki eden durumlar teması PISA ve mevcut sınav sistemi ilişkisi kategorisine yönelik görüşleri

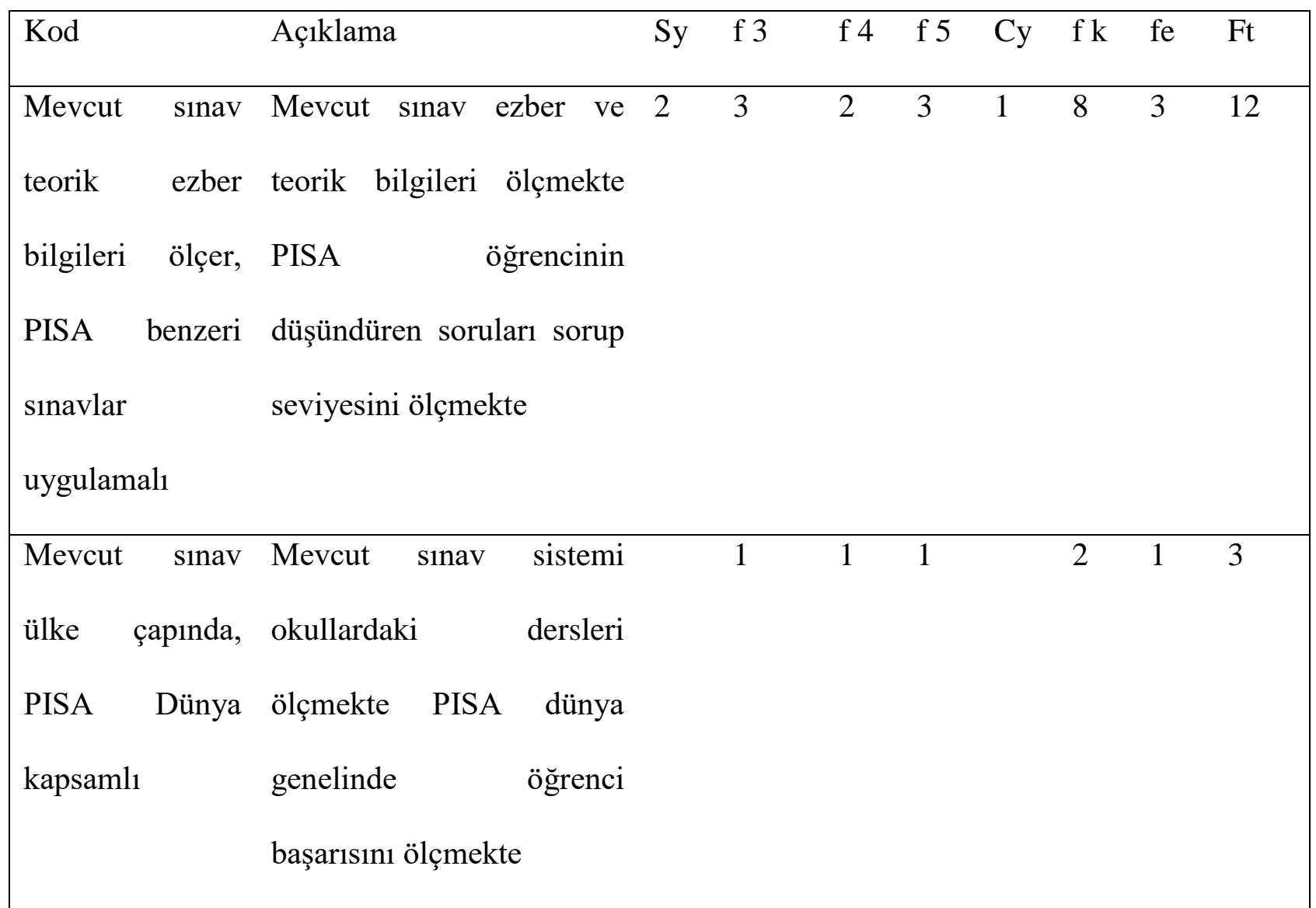

Tablo 6 incelediğinde katılımcı öğrenciler genel olarak Türkiye’deki mevcut sınavın teorik bilgileri ölçmeye yönelik, PISA’nın ise uygulamalı ve günlük hayat bilgilerini ölçmeye yönelik olduğunu belirtmişlerdir.

Tablo 7 

öğretmenlere yönelik öneriler kategorisine ilişkin analiz sonuçları

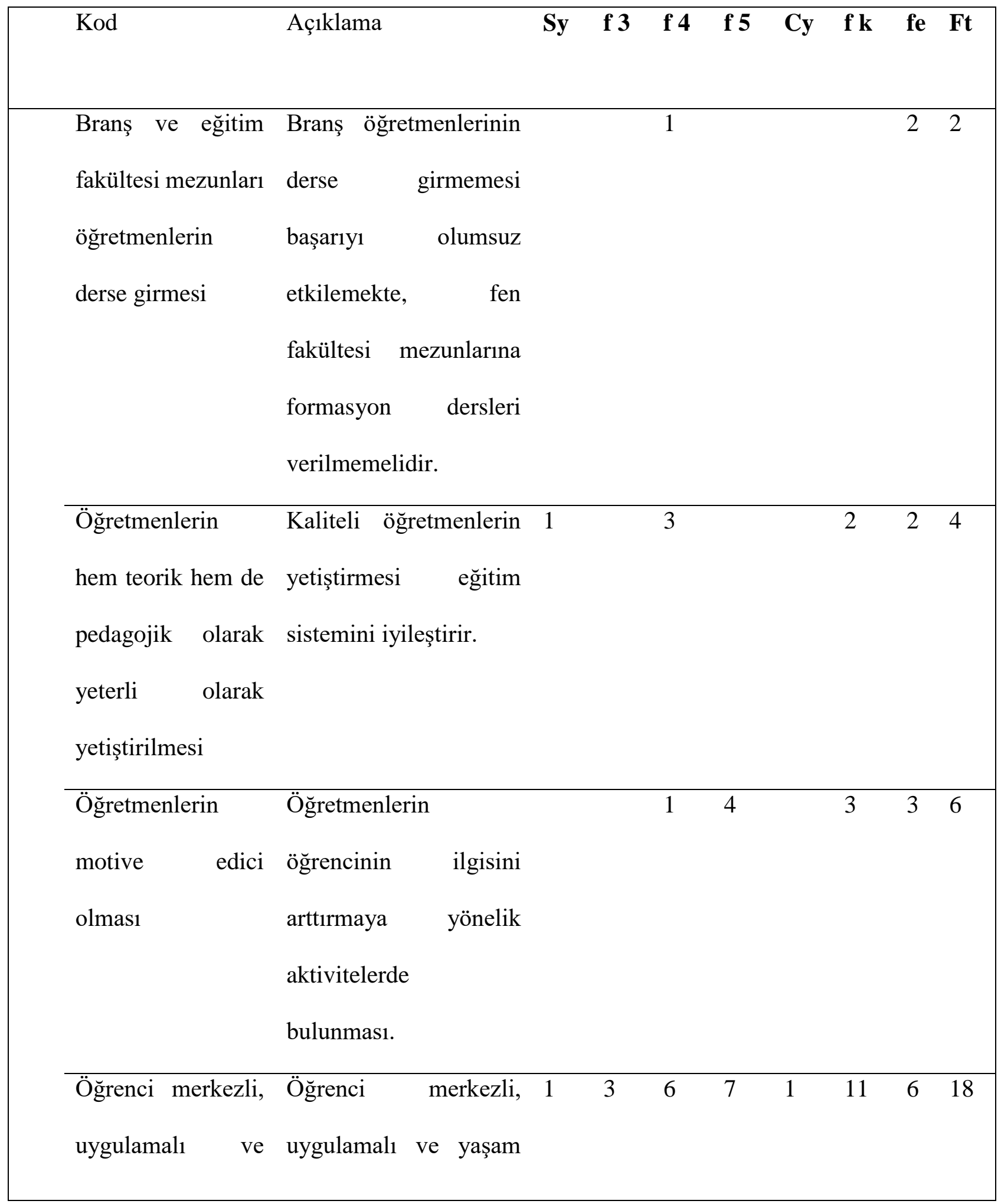


yaşam temelli temelli eğitimin

eğitimin verilmesi verilmesi.

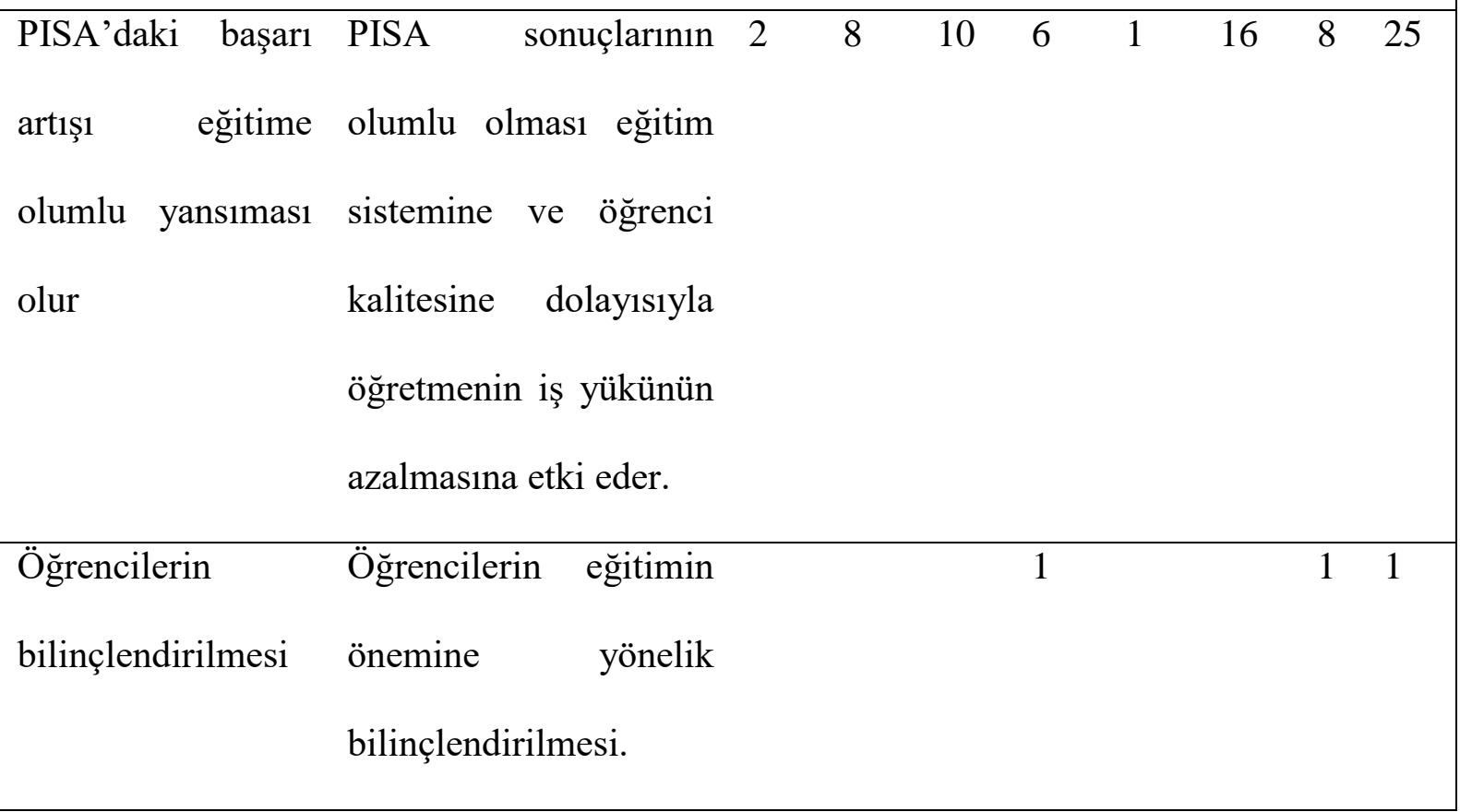

Tablo 7’ye bakıldığında katılımcılar, daha iyi bir eğitim sistemine sahip olmak için öğretmenlerin donanımlarının yeterli düzeye getirilmesi, motivasyonlarının arttırılması, PISA'daki başarının arttırılması ile öğretmenin iş yükünün azaltılması, öğrencilerin bilinçlendirilmesi, eğitim fakültesi mezunu branş öğretmenlerinin derslere girmesi gerektiğini ifade etmişlerdir.

\section{Tablo 8}

Katılımcı öğrencilerin Türkiye’nin PISA sınavlarındaki başarısının artmasına yönelik önerileri teması ders içeriklerine yönelik öneriler kategorisine ilişkin analiz sonuçları

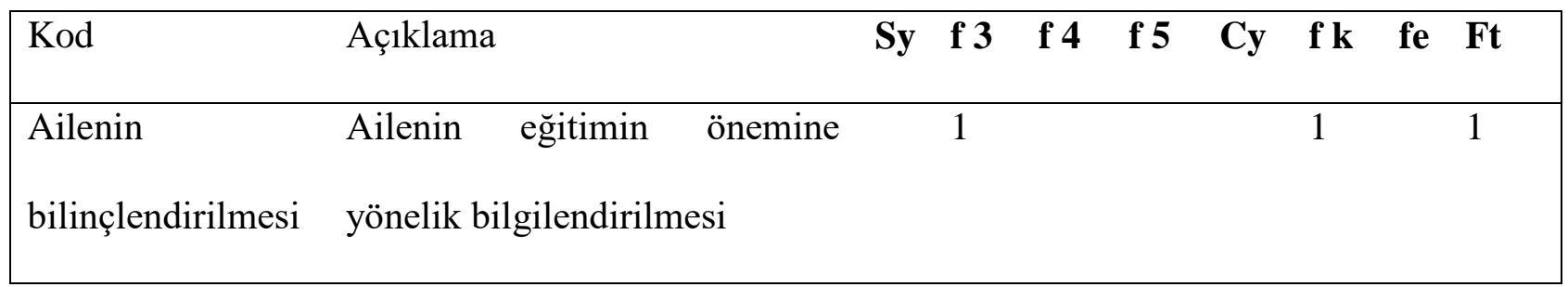




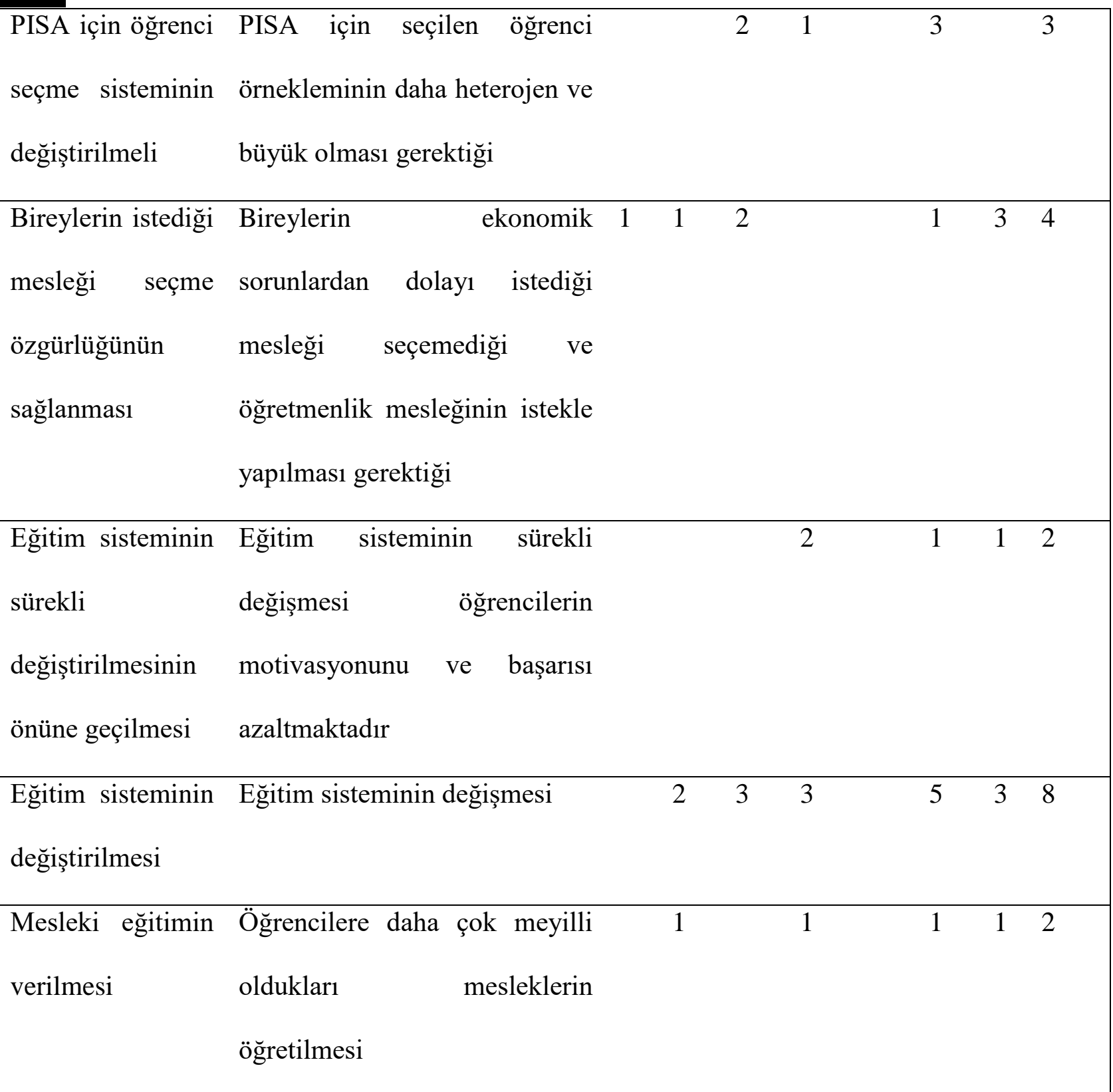

Tablo 8'deki bulgulara göre araştırmaya katılan grubun daha iyi bir eğitim sistemi için önerileri incelendiğinde, bireylerin meslek seçiminde özgür bırakılması, mesleki eğitimin verilmesi, öğrenci merkezli olan yaşam temelli yöntem-teknikleri benimsemesi ve eğitim sisteminin değiştirilmesi gerektiği yönünde önerilerde bulundukları görülmüştür.

Araştırma yapıldıktan sonra, incelenen formlardan elde edilen bazı öğrenci ifadeleri olduğu gibi alıntılanmıştır. Pisa programları hakkında bilginiz var mı sorusuna A öğrencisi şöyle cevap 

öğrencisi ise "Hayır hiçbir bilgi sahibi değilim" diye yanıtlamıştır. Türkiye'nin OECD ülkeleri arasındaki fen okuryazarlık başarısı açısından son sırada olmasının nedenlerine yönelik soruya C öğrencisi “Ĕgitimin öğretmeye yönelik değil sinavlara yönelik olmasından dolayıdır” şeklinde cevap vermiştir. Aynı öğrenci "öğretmenlerin ve velilerin sonuç odaklı olmasından dolayı" şeklinde ifadelerine devam etmiştir. Bu sonuçların mevcut duruma ve gelecekteki yansımalarına yönelik soruya D öğrencisi şöyle cevap vermiştir; “Ĕgitim sisteminde köklü bir değişim olmadığl ve sistemin sınava yönelik devam etmesi halinde sürekli böyle olacaktır”. Bir başka E öğrencisi ise "Ĕ̆itim sistemimiz maalesef kötü, sürekli bir iyiyi arama arayışı olduğu için sistemler oturmadan değiştirmek kötü olmuştur" şeklinde cevap vermiştir. Türkiye'deki sınavlar ile pisa sınavları arasında karşılaştırmaya yönelik soruya F öğrencisi “mevcut sınavlar tamamen ezbere dayalı sınavlar. Ancak PISA programı sınavları ise açık uçlu ve karmaşık sorulardan oluşuyor. Yani ögrenciyi düşünmeye sevk edecek sorular" diye cevap vermiştir. Araştırmada PISA sınavı fen okuryazarlık başarısının arttırmasına yönelik neler yapılabileceğine ilişkin sorulan soruya bir öğrenci şöyle cevap vermiştir; “Öncelikle fizik pozitif bir bilim. Öğrenci ezbere ya da tamamen teoriye boğulmamalt. Kavrayarak ve görerek, deneyerek ögrenilmesi gerekir. Pek sevilen bir ders de dĕ̆il maalesef. İşe fiziği sevdirecek ilgi çekici yönlerini öğrenciye göstererek başlanmalı. Dersler sınıftan çok laboratuvarda geçmeli. Öğrenci böyle çok daha iyi ögrenir".

\section{Tartışma ve Sonuç}

Araştırmadan elde edilen en dikkat çekici bulgulardan birisi, katılımcı fizik öğretmen adaylarının önemli bir çoğunluğunun bu sınavın ne olduğuna dair bir fikirlerinin olmayışıdır. Geleceğin öğretmenleri olan bu katılımcı fizik öğretmen adaylarının uluslararası düzeyde yapılan önemli sınavlardan biri olan bu uygulamadan haberdar olmamaları oldukça çarpıcı ve olumsuz bir durumdur. Bu bulgudan hareketle katılımcı fizik öğretmen adaylarının çağın gereklerine uygun, 
güncel gelişmelerden haberdar olacak şekilde yetişmediklerini söylemek mümkündür. Bu noktada, eğitim fakültelerinde yürütülen eğitim faaliyetlerinin de sorgulanması gerekmektedir. Nitekim Simola (2005), Finlandiya'daki öğrencilerin PISA sınavlarında elde ettiği başarının altında, nitelikli öğretmen eğitiminin olduğunu ifade etmiştir. İyi yetiştirilmiş, donanımlı öğretmenler nitelikli eğitimi sisteminin en önemli bileşenlerindedir. Erarslan (2009) Finlandiya'daki öğretmen yetiştirme programını incelemiş ve Türkiye için de öğretmen kalitesinin arttırılmasına yönelik önerilerde bulunmuştur. Araştırmacı, yüksek lisans mezunu öğretmen adaylarına sınavsız atama hakk1 verilmesi, ekonomik destek gibi yöntemlerle öğretmen kalitesinin arttırabileceğini ifade etmiştir. Yine katılımcı fizik öğretmen adaylarının üzerinde önemle durduğu bir başka sorun ise eğitim sisteminin yetersizliği olarak karşımıza çıkmaktadır. Katılımcılar mevcut eğitim sisteminin öğrenci potansiyelini ortaya çıkaramadığını, yeteri kadar nitelikli olmadığını çoğunlukla ifade etmişlerdir. Oysa ki Berberoğlu (2007) bu konudaki bir çalışmasında Türkiye'deki fen lisesi, Anadolu lisesi ve özel okul öğrencilerinin başarılarının OECD ülkelerinin başarı ortalamasının üstünde olduğunu dile getirmiştir. Yazar buradan hareketle Türkiye'nin istenilen başarıyı yakalama potansiyelinin mümkün olduğunu ve eğitim politikalarında, diğer liselerdeki başarısızlık nedenlerinin araştırılarak performansın arttırılmasına yönelik düzenlemelerin yapılması gerektiğini vurgulamıştır. Eğitim sisteminin eksiklikleri ile bağlantılı olarak, katılımcı öğretmen adaylarının önemli bir kesimi, kendilerine verilen PISA programı bilgilendirme formunu okuduktan sonra, PISA sınavlarının öğrenci merkezli, Türkiye'deki mevcut sınavların ise ezberci bir yaklaşımın ürünü olduğunu ifade etmişlerdir. Yine bu bulguya paralel olarak araştırmaya katılan öğretmen adayları en fazla öğrenci merkezli ve yaşam temelli uygulamaların olmayışına dikkat çekmişler ve bu uygulamaların öğrenme ortamlarında yapılması gerektiğini ifade etmişlerdir. Türkiye'de 2007 yılından itibaren lise ders içerikleri öğrenci merkezli ve yaşam temelli uygulamalar temel alınarak düzenlenmiştir. Fakat yapılan araştırmalar, ders kitaplarındaki öğrenci merkezli etkinliklerin büyük oranda yapılmadı̆̆ını, öğrenme ortamlarında öğretmenlerin, öğretmen merkezli yöntem ve teknikleri kullanmaya devam 
ettiklerini göstermiştir. Öğretmenlerin yeni uygulamalara, öğrenci merkezli etkinliklere yönelik olumsuz yaklaşımlarını inceleyen çalışmalar mevcuttur. Örneğin Mete ve Yıldırım (2016) öğretim elemanları ile yaşam temelli öğrenme üzerine bir araştırma yapmışlardır. Araştırmanın sonucunda katılımcılar, öğretilecek konularla ilgili bağlam hazırlamada yaşadıkları zorluk, öğrenci merkezli etkinliklerin zaman alması, öğrencilerin daha çok sınavlara yönelik çalışmaları gibi olumsuz faktörlere vurgu yapmışlardır. Öğrenci merkezli uygulamalarda araç- gereç yeterliliği oldukça önemlidir. Nitekim Özay Köse ve Çam Tosun (2011) yaptıkları çalışmada katılımcı fen öğretmenlerinin yaşam temelli öğretim etkinliklerinde kullanacakları materyalin yetersiz oluşu ile ilgili kaygı yaşadıklarını aktarmışlardır. Araç-gereç eksikliği öğrenme ortamlarında rastlanılan önemli yetersizliklerden biridir (Baran, Maskan ve Yaşar, 2018). Bu noktada Türkiye’deki eğitim harcamalarının OECD ülkeleri arasındaki durumuna bakmakta fayda vardır. Çünkü yapılan araştırmalar Türkiye'nin eğitim harcamalarında OECD ülkelerinin ortalamasının altında kaldığını göstermektedir (Egeli ve Hayrullaoğlu, 2014). Tüm bu bulgulardan hareketle okullardaki altyap1 eksikliğini gidermeye yönelik girişimlerin, öğrenci merkezli uygulamaların daha sağlıklı bir şekilde uygulanmasına olanak sağlayacağı düşünülmektedir.

Katılımcı öğretmen adaylarının PISA sınavı sonuçlarını değerlendirirken oldukça yerinde tespitler yaptıkları görülmüştür. Özellikle sınav sistemi ve öğrenci merkezli uygulamalar birbiriyle direk bağlantı içerisinde olan kavramlardır. Sınav sistemi değiştirilmediği sürece öğrenci merkezli uygulamaların hem öğretmenler hem de öğrenciler tarafından pek benimsenmediği görülmektedir. Baran (2011) tez çalışmasında öğrenci merkezli deneysel bir çalışma yapmış ve süreç sonunda öğrencilerden görüş almıştır. Öğrenciler uygulamalardan keyif aldıklarını söylemekle beraber üniversite giriş sınavı hazırlıkları için ayrılan süreyi zaman kaybı olarak gördüklerini, bu süre zarfında daha çok sınava yönelik soru çözebileceklerini ifade etmişlerdir. Bu bulgulardan hareketle sınav sisteminin de deney, gözlem ve yaparak yaşayarak öğrenmenin baz alındığı ders içeriklerine paralel olarak düzenlemesinin daha yararlı olacağı düşünülmektedir. Öğrenci merkezli uygulamalar, 
öğrencilerin bilimsel süreç ve problem çözme becerilerini geliştirmeye ve bilimsel okuryazar olmalarına yönelik ise, buna paralel olacak şekilde bir sınav sistemi ile ölçme ve değerlendirme yapılması daha uygun olacaktır. Ancak bu şekilde öğrenci merkezli uygulamalar daha sağlıklı yürüyebilir. Türkiye' deki mevcut sınav sisteminin, fizik ders kitapları içeriklerinde belirtilen öğrenci merkezli yöntem ve tekniklerin öğrenme ortamlarında kullanılmasını olumsuz etkilediği düşünülmektedir.

Katılımcı fizik öğretmen adaylarının belirttiği ve bulgular kısmında açıklanan Türkiye'de fen eğitimi alanında ve öğretmen yetiştirme sisteminde var olan sorunların çözülmesi durumunda; PISA sınavı gibi uluslararası programlarda başarılı ve 21. Yüzyıla uygun temel süreç becerilerine sahip öğrenci sayısının artabileceği ideal bir düzeye gelinebilir.

\section{Makalenin Bilimdeki Yeri}

Fizik Eğitimi, Fen Eğitimi

\section{Makalenin Bilimdeki Özgünlüğ̈̈}

Türkiye'nin PISA sınavlarındaki başarısızlığına yönelik çeşitli çalışmalar mevcut iken, geleceğin öğretmenleri olacak olan öğretmen adaylarının bu durumun ne kadar farkında olduklarına yönelik bir inceleme çalışmasına rastlanmamıştır. Bu durum göz önüne alınarak yapılan bu araştırmada fizik öğretmenliği anabilim dalında eğitim görmekte olan öğretmen adaylarının PISA sınavlarından haberdar olup olmadıkları ve Türkiye'deki öğrencilerin PISA fen bilimleri sınavı sonuçlarına yönelik görüşleri değerlendirilmiştir. Böylelikle ilgili alan yazınına katkıda bulunulacağ düşünülmektedir.

\section{Kaynakça}


Baran, M. (2011). Teknoloji ve proje tabanlı öğrenme yaklaşımı destekli düşünme yolculuğu tekniğinin lise 11. sını öğrencilerinin fizik başarısı ve akademik benlik tasarımına etkisi. Yayınlanmış Doktora Tezi, Dicle Üniversitesi.

Baran, M., Maskan, A.K., \& Yaşar, Ş. (2018). Learning physics through project-based learning game techniques. International Journal of Instruction, 11(2), 221-234.

Berberoğlu, G. (2007). Türk bakış açısından PISA araştırma sonuçları. Konrad. Adenauer Stiftung.

Çelen, F. K., Çelik, A., \& Seferoğlu, S.S. (2011). Türk eğitim sistemi ve PISA sonuçları. Akademik Bilişim, 2-4 Şubat/İnönü Üniversitesi.

Egeli. H., \& Hayrullahoğlu, B. (2014). Türkiye ve OECD ülkelerinde eğitim harcamalarının analizi. Finans Politik \& Ekonomik Yorumlar, 51(593)

Eraslan, A. (2009). Finlandiya'nın PISA' daki başarısının nedenleri: Türkiye için alınacak dersler. Necatibey Ĕgitim Fakültesi Elektronik Fen ve Matematik Ĕ̆itimi Dergisi (EFMED), 3(2), 238-248.

Mete, P., \& Yıldırım, A. (2016) Yaşam temelli öğrenme yaklaşımının kimya derslerindeki uygulamaları hakkında öğretim elemanlarının görüşleri. Journal of Bayburt Education Faculty, 11(1)

Miles, M.B., \& Huberman, A.M. (1994). Qualitative data analysis, 2nd Ed., p. 10-12. Newbury Park, CA: Sage.

Özay Köse, E., \& Çam Tosun, F. (2011). Yaşam temelli öğrenmenin sinir sistemi konusunda öğrenci başarılarına etkileri. Türk Fen Eğitimi Dergisi, 8(2), 91-106.

PISA 2012 Raporları, http://egitimplatformu.aydin.edu.tr/gundem/haber_detay.asp?haberID=25 Erişim tarihi 28.02.2015 
Sarıer, Y. (2010). Ortaöğretime giriş sınavları (OKS-SBS) ve PISA sonuçları 1şığında eğitimde fırsat eşitliğinin değerlendirilmesi. Ahi Evran Üniversitesi Eğitim Fakültesi Dergisi,11(3), $107-$ 129

Simola, H. (2005). The Finnish miracle of PISA: Historical and sociological remarks on teaching and teacher education. Comparative Education, 41(4), 455-470.

\section{Summary}

Problem Statement: What is expected from individuals of the $21^{\text {st }}$ century is not to become a storage of information but to be capable of applying and synthesizing that information. The way to develop this ability is to take good-quality education. The primary function of education can be defined as allowing the learner to get the information in a way to criticize, interrogate and structure the information on his or her own. In this way, meaningful learning can be achieved. This situation is important not only because it starts from pre-school period and goes on with higher education and with subsequent phases but also it has indirect influence on the general structure of the society. In this respect, it is also important how effectively education systems function. Therefore, there are various measurement and evaluation mechanisms on national as well as international basis. One of these mechanisms is the PISA program, which is an international student evaluation program applied to fifteen-year-old high school students.

When the results of the exam applied within the scope of PISA program are examined, it is seen that the success levels of the students participating in this program in Turkey is quite low when compared to those in many other countries. This situation has led to questioning the education system. Researchers who conducted studies in various fields of education investigated the causes of this situation. However, the students from Turkey who took the exams within the scope of PISA program have failed to achieve the desired success in the fields of mathematics, science and reading skills. Therefore, it could be stated that in Turkey, students experience problems while criticizing, 

with the education system still exist. Review of the related literature revealed that there is no research investigating the views of teachers or preservice teachers about international education programs and evaluation systems. For this reason, the present study is thought to contribute to the related literature.

\section{Research Purpose}

In this study, the purpose was to reveal whether preservice teachers from the department of Physics Teaching were aware of PISA exams and to evaluate the views of students in Turkey about the PISA science exam results.

Method: The study was carried out with 49 physics preservice teachers. In the study, the qualitative research method was applied. The data collected in the study were analyzed using content analysis and descriptive analysis methods.

Findings: The analysis results revealed that of all the 49 students, 40 of them did not have any information about PISA exams. It was seen that among all the participants, eight of them knew something about the program, while one of the students had wrong information about the program. In addition, regarding the failure in science literacy, most of the physics preservice teachers participating in the study reported that the curricula were insufficient and exam-based requiring memorization and that the curricula thus failed to motivate students. Also, it was seen that the students' negative views about the socio-economic level and the current exam system ranked second and third in terms of frequency. When the participants' suggestions for a better education system were examined, it was found that they mostly focused on the role of the teacher and that they any decrease in the teacher's work load would have influence on students' success. In relation to increasing science literacy, the preservice teachers also suggested that teachers from the fields of science could adopt student-centered and life-based methods and techniques and that the education system should be changed. 
Conclusion: As mentioned by the physics preservice teachers participating in the study, when the problems experienced in the field of science teaching in Turkey and those encountered within the scope of the teacher-training system are solved, the number of students who have the basic process skills appropriate to the $21^{\text {st }}$ century and who are successful in international programs like the PISA exam will increase to the desired level.

EK. PISA sınavlarına yönelik fizik öğretmen adaylarına yöneltilen sorular

S1. Pisa programları sınavları hakkında bilginiz var mı? Pisa sınavlarının amaç, içerik ve uygulandığı katılımcı grup v.b. konularında görüşleriniz nelerdir?

S2. Pisa programları sınavlarında Türkiye'den katılan öğrencilerin fen okuryazarlık başarısı durumu konusunda bilginiz var mı?

S3. 2003 yılından beri yapılan Pisa programları sınavlarında Türkiye'den katılan öğrencilerin fen okuryazarlık başarı durumu açısından OECD ülkeleri arasında son sıralarda yer almaktadır. Bu durumun nedenlerine ilişkin görüşleriniz nelerdir?

S4. Pisa programları kapsamında fen okur yazarlık boyutunda elde edilen bu sonuçların gelecek nesiller açısından önemine ilişkin görüşleriniz nelerdir?

S5. Fizik öğretmeni adayı olarak bu sonuçların size bir yansımasının olduğunu veya olacağını düşünüyor musunuz? Neden?

S6. Pisa programı sınavında sorulan fen okur yazarlık seviyesini ölçen sorulara ilişkin görüşleriniz nelerdir?

S7. Türkiye'deki mevcut sınav sistemindeki sınavlar ile Pisa programı sınavları arasında nasıl bir bağlantı kurabilirsiniz? Hangisinin daha geçerli ve güvenilir olduğunu düşünüyorsunuz?

S8. Pisa programları sınavlarında elde edilen fen okur yazarlık seviyesi başarı durumunun daha iyi bir noktaya getirilmesine yönelik önerileriniz nelerdir? 